\title{
The Contribution of Integrated Polytechnic Regional College (IPRC) Musanze in Creating Valuable Uses to Tomato Crop Farm-Leftovers
}

\author{
Aimable Uwihanganye ${ }^{1^{*}} \quad$ Arno de Snoo $^{2}$ \\ 1. Rwanda Polytechnic-Integrated Polytechnic Regional College Musanze, PO box 226, Musanze, Rwanda \\ 2. Van Hall Larenstein University of Applied Sciences, PO box 9001, 6880 GB Velp, Netherlands
}

\begin{abstract}
The study was carried out to identify potential value addition to tomato crop farm-leftovers and investigate their existing end-uses to suggest a collaboration model between tomato farmers in Nkotsi Sector and IPRC Musanze. The findings confirmed that the tomato crop stems are the main type of tomato crop farm-leftovers found on the farm, leaves and roots are also present in minor quantities. Those farm-leftovers are mainly used for compost making, some remain unused at farm level, and few are used for feeding animals. For whatever destination, the tomato crop farm-leftovers do not generate any cash to farmers, and unfortunately, $91 \%$ of farmers are not aware of crop farm-leftovers negative effects. All respondents know the IPRC Musanze, and 59\% of them recognize its community outreach activities. However, $97 \%$ of farmers do not have any previous collaboration with the college even though they show willingness for future collaboration. $62 \%$ of interviewed IPRC Musanze TVET trainers revealed limited advanced tomatoes farming activities in the area, and crop farm-leftovers negative effects. A collaboration model between farmers and the college is designed as a new way of working to boost tomato farming in the area as well as improving the quality of TVET training offered by the college. The stable relations, trust, shared problem, resources, planned joint activities and their execution are the elements of the proposed model. Therefore, technical training, joint applied research and innovation activities, joint problem-solving initiatives were suggested as the starting point for the proposed model.
\end{abstract}

Keywords: Tomato crop, farm-leftover, TVET, collaboration

DOI: $10.7176 / \mathrm{JEP} / 12-3-01$

Publication date: January $31^{\text {st }} 2021$

\section{Introduction}

1.1. Background of the study

The world counts 7.3 billion people and the number may reach 9.9 billion by 2050 (UN, 2019). That number is directly linked to the global unprecedented increased demand for food from $59 \%$ to $98 \%$ by 2050 . The feed and fuel demand will also increase probably due to underutilization of agricultural and horticultural production byproducts (Junker-Frohn, et al., 2019). Global sustainability requires a lot of effort in different domains and one of the key challenges to be addressed relate to agriculture and its entire affiliated subsectors. According to LSU AgCenter 2018, horticulture is "science and art involved in the cultivation, propagation, processing, and marketing of ornamental plants, flowers, vegetables, fruits, and nuts". Tomato, one of the horticultural crops is considered as highly produced and gradually consumed in Rwanda, but its primary production is seasonal, and the crop is highly perishable (Mukantwali et al., 2018). The tomato crop has a very high social importance and the active farmers raise their economy directly or indirectly through the involvement of its cultivation (Singh et al., 2019). During its production especially in postharvest activities, tomato crop produces a huge number of discarded/unvalued residues at farm level, trashes at the fresh market as well as rubbish at the processing units. Among those residues, about $33 \mathrm{~kg}$ of leaf and stem biomass per $100 \mathrm{~kg}$ of harvested tomatoes accrue during and at the end of the growing period (Junker-Frohn, et al., 2019). Although stem biomass contributes to about $70 \%$ of the residual green biomass after harvesting, each tomato plant generates about $0.75 \mathrm{~kg}$ of leaf biomass, resulting in about $15 \mathrm{t} \mathrm{ha} \mathrm{H}^{-1}$ (JunkerFrohn et al., 2019). The large quantities of discarded plant biomass from primary production are either used for biofuel production, composted, or are discarded with costs (Junker-Frohn et al., 2019).

Although it is a simple crop residue disposal method, burning has an excessively negative impact on the agriecosystem as it produces a lot of small particles in the environment and causes air pollution as well as disturbance of soil physical, chemical and biological components that affect also microflora and microfauna life (Pratap Singh and Prabha, 2018). Therefore, the valorization of crop-residues is an imperative action to improve soil structure, crop productivity, and protect the environment. The recommended use of improved harvesting methods, postharvest handling technologies to be adopted by farmers are possible in Rwanda and other Sub-Saharan African countries, but still, there is a need for value addition of the tomato crop leftovers/residues at farms' location (Crump, 2016).

Furthermore, all initiatives targeting the upgrading of farmers' activities require the skilled and well-trained technical workforce. The hand-on competences are mainly obtained through Technical and Vocational Education 
Training (TVET) schools having various domains of specialization (agriculture, irrigation, construction, hospitality, Information Technology, etc.). In Rwanda TVET schools at a higher learning level are known as Integrated Polytechnic Regional Colleges (IPRCs) and are governed through Rwanda Polytechnic (RP). The RP is a higher learning technical institutions umbrella that was established by law $\mathrm{N}^{\circ} 22 / 2017$ of 30/05/2017 determining its mission, powers, organization, and functioning. The Law established RP as Higher Learning Institution, an organ with legal personality and enjoys administrative, teaching, research and financial autonomy and it is managed following relevant laws. The RP has eight (8) colleges where the action of teaching-learning and research happens.

According to MIFOTRA (2017), the main mandate of RP is to address the issues and problems of Rwandan communities, especially youth unemployment and limited labour opportunities, partly caused by a lack of relevant labour technical skills. The adopted way forward for RP is creating a strong partnership with different stakeholders to address the labour market requirements. Therefore, RP through its affiliated IPRCs wants to graduate a highly skilled and well-trained workforce and link them to current and future societal needs. Rwanda is rapidly transforming into a competitive knowledge-based economy that requires new ways of teaching and learning accompanied by applied research to address community challenges. The main mandate of IPRCs is to train the practical workforce ready to make changes in the Rwandan community and provide creative and innovative solutions to societal problems through applied research. Additionally, IPRCs are mandated to be engaged in community outreach services (skills transfer, research, innovation, community works, etc...) to support, contribute, and solve the developmental problems within the surrounding community.

\subsection{Problem statement}

Rwanda has a strong agriculture competitive base founded on its natural environment elements such as good climate, abundant rainfall, high fertile soils, and enough labour force that are used to produce quality and competitive horticultural products $(\mathrm{RDB}, 2020)$. This encouraging farming environment helps farmers to produce reasonable quantities of tomatoes throughout the year (Kitinoja et al, 2019). The tomatoes' primary production generates a high amount of crop farm-leftovers which are not yet profitably used and when improperly managed they become a source of environmental issues such as air pollution, crop diseases, and contribute to climate change issues. On the other hand, IPRC Musanze, a well-equipped and capacitated TVET higher learning institution is not generally contributing enough to local farming challenges via its offered technical courses like Agriculture and Food Processing course which is trending nowadays. Therefore, there is a knowledge gap about the non-existence of a formal problem-solving collaboration between tomato farmers in the Nkotsi Sector and IPRC Musanze to jointly address tomato farming challenges (e.g. farm-leftovers valorization). This is one of the starting points to develop a tomato farming business coupled with enhancement and application of the practical training and applied research from the college.

\subsection{The study objective}

The objective of the present study is to identify potential value addition activities to tomato crop farm-leftovers and investigate the current farm-leftovers uses, to suggest collaboration model between tomato farmers in Nkotsi Sector and IPRC Musanze as a channel of solutions provision on tomato farming development challenges

1.4 The study questions

This study has two main research questions and three sub-questions for each as mentioned below.

Main question 1: What are the estimated amounts and current uses of tomato crop farm-leftovers in Nkotsi sector?

1.1What type and how much quantity of tomato crop farm-leftovers from Nkotsi Sector?

1.2What are the final destinations of farm-leftovers along the tomato value chain in Nkotsi sector?

1.3What are the monetary benefits from tomato crop farm-leftovers in Nkotsi Sector?

Main question 2: What are the potential value addition processes that can be applied to tomato crop farm-leftovers?

2.1What are the value-added activities to transform tomato crop farm-leftovers into other products?

2.2What are the technical requirements to create valuable products from tomato crop farm-leftovers?

2.3What could be the joint value addition activities between tomato farmers and IPRC Musanze?

\section{Literature review}

\subsection{Value chain description}

The chain of values is explained as a tree with various branches and each of them representing an end-product (KIT, Mali and IIRR, 2010). As the name states, within a value chain, various actors are involved. The key actors directly involved in the chain are known as primary actors (e.g.: input suppliers, farmers, transporters, processors, wholesalers, consumers). The other indirect actors are known as chain supporters (e.g.: policy-making agency, financial institutions, quality standard). Generally, the term "value chain" is defined differently depending on the context it is used for. In the agricultural sector, the value chain (VC) is a set of activities and actors that work 
together to bring a basic agricultural product from primary production in the field to its final step of being used or consumed, where at each stage value is added to it (Madhovi, 2020). One of the wings of the value chain is named "support environment" composed of value chain stakeholders (both public and private) that provide support services. The latter may include services offered by training and research development institutions, services from agricultural extension offices, innovative opportunities from agribusiness establishments dealing with Agricultural Value Chains (Foundation of Abomey-Calavi University, 2018). The categories of universities and research institutes are the middle level of interaction between the agricultural sector and educational scientific institution (CBI, 2015). This interaction results in the provision of support services that help to solve certain agriculture technical problems (i.e.: improvement of varieties, formulation and trial of new fertilizer, biological control, optimal production technique, innovation in postharvest handling, etc.). The chain activities are not always static along the way of the crop production; consequently, the Value Chain Development (VCD) terminology is familiar in the discussion of the crop production chains. According to Donovan et al., 2015, VCD is explained as the discovery of unfamiliar options to enrich opportunities for smallholder chain actors' participation in the establishment of new linkages between them and favourable markets. This enhancement also is based on the description of the context whereby the VC is to be developed. Some VCD approaches do not target only the production and marketing of a new product, some focus on the design of new intervention and interaction among chain actors, while others can only deal with the development of a new value chain that links smallholders to national or export markets. Whatever the adopted approach, it is influenced by the political, legal, and business environment where the value chain is implemented (Donovan et al., 2015).

\subsection{Tomato value chain}

Tomato is ranked the second worldwide fresh and processed crop after potato. Epi Heuvelink (2018) classifies tomatoes in the family of Solanaceae, with the genus of Solanum in the section of Lycopersicon. The Solanaceae family is large and contains more other vegetable crops like aubergine (Solanum melongena), chilli and bell peppers (Capsicum spp.), potato (Solanum tuberosum), tamarillo or tree tomato (Solanum betaceum), tobacco (Nicotiana tabacum), and tomatillo (Physalis ixocarpa). Sarma (2019) explains the tomato value chain as the addition of values to the tomato product as it moves from input suppliers as the first step and goes through producers and finally to consumers. From stage to stage throughout the value chain, the product is modified by chain actors and the incurred transaction cost reflects the form of value-added and generally its appearance and economic facet change from one stage to another depending on the effort made. The production of tomatoes starts with the supply of various inputs needed like seed, fertilizer, pesticide, and others. After the supply of all the input, the second function is the production/ farming that is followed by harvesting, collection, and transportation, processing as well as trading before the end-use and or consumption of the final product. Along the whole tomato value chain, various actors perform different functions as the product moves from one step to another, and the product value increases depending on effort exercised by chain actors. Along the way, there are always residues/leftovers at each step of the value chain. In most of the times after obtaining the primarily intended product on a given value chain stage, the remaining is useless (Karim and Biswas, 2016).

\subsection{Tomato production in Rwanda}

Tomato is considered as a crop with the highest value, ranked the second largest vegetable highly produced and consumed in Rwanda (Mukantwali et al., 2018). Tomatoes are domestically marketed as well as sold in bordering countries of Rwanda as fresh fruit and its processed form. Tomato is an essential crop for Rwandan, and it is classified as both food and cash crop and its productivity in Rwanda increased at 300\% in 2008 and 2010 (Mwongera et al., 2019).

2.3.1 Production areas

The tomato crop is cultivated in various districts in Rwanda because it is farmed in 11 districts out of 30 districts of the countries. According to Fortune of Africa (2013), tomatoes in Rwanda are mostly grown in the following districts: Bugesera District; Rwamagana District; Kayonza District; Rusizi District; Nyagatare District; Gatsiro District; Burera District; Musanze District; Nyanza District; Nyamasheke District; and Huye District. The total tomatoes production in Rwanda for the last five years (2014-2018) is 548042 tons on a total harvested area of 49 $452 \mathrm{ha}$. The interesting observation is that the harvested areas have been increasing for the first four years and decreasing for the fifth year while the total of tomatoes produced has been increasing for the first three years and decreasing in the fourth and the fifth year. The statistics show on average 11 tons of tomatoes produced from one hectare (FAO, 2019).

2.3.2 Tomato Production challenges

Despite the reasonable tomatoes production in Rwanda, the horticultural sub-sector faces several challenges. Mukantwali et al., (2018) show through the Commodity Systems Assessment Methodology report that farmers face postharvest losses on average $21 \%$ of their crop during harvesting, $11.5 \%$ of tomatoes are lost the collection point, $10 \%$ of tomatoes are lost at the wholesaling level while $13.6 \%$ of tomatoes are culled out and discarded at 
the retailing places. The subsequent post-harvest losses are connected to over mature tomatoes, improper postharvest handling activities, poor quality containers which create rough transportation. These postharvest challenges consequently result in tomato prices fluctuations at the local market thus affecting farmer's profitability as well as farming development (Mwongera et al., 2019). Apart from postharvest losses, generally, players in horticulture sector face other challenges in their farming business to note: competition between locally processed and imported tomato products; lack of skills in modern farming; pests and diseases affecting tomato production; incapacity of local value addition to produced tomatoes, and the gap in market knowledge (Fortune of Africa, 2013).

2.4 Agricultural crop leftovers and their products

Along the way, in the agricultural value chain, some materials are either intentionally or not discarded. The unintentionally agricultural materials produced at the farm are considered as waste because they are not primarily intended products. UN (2016) defines agricultural waste as any materials that are not primarily produced for the market and are the results of production, conversion, consumption, and most of the times are discarded. These agricultural leftovers may result from harvesting and post-harvesting activities such as modification of raw materials, transformation into other products, the end products consumption, and other human activities. Those remaining materials are taken as useless and discarded but in reality; they are biological materials that can be recycled, valorized, and reused for other purposes as well as generating additional income to farmers. Agricultural crop wastes/leftovers are generally divided into pre-harvest wastes, harvesting time wastes, and post-harvest wastes (Ari Aprianto, Dryanto, and Sanim, 2016).

The pre-harvest agricultural wastes are generated from nursery operations and maintenance of immature plantations that are usually in the form of generative and vegetative parts of crops that have fallen (leaves and twigs) but it can also be the discarded material. The post-harvest residues include those from the transfer activities from the field to storage facilities, and transportation before being sold to a processing factory (Ari Aprianto, Dryanto, and Sanim, 2016). The management of agriculture wastes to prevent their negative impact on the environment requires stakeholder's collaboration. The joint efforts from concerned players may solve the problem of the knowledge gap across organizations and it requires extending the capability of partners to accomplish a continuous improvement through problem-solving innovations (Handayati, Simatupang and Perdana, 2015). According to Fritsch et al (2017), the global major concerns nowadays are the huge amount of agricultural and food wastes that need sustainable solutions in creating profitable utilization as well as reducing the environmental burden. Various agricultural leftovers possess potential uses and can be valorized through diversified technologies and contribute to monetary benefits to farmers and environmental advantages to the whole society. Trung Hai and Anh Tuyet (2010) describe the advantage of the decomposed agricultural materials as not only providing indispensable nutrients for plant growth and development but also their important role in soil characteristics, particularly its water holding capacity, contribution to sustainable agriculture, and clean and safe environment. The post-harvest agricultural materials contain organic macronutrients (hydrocarbons, proteins, lipids) and microelements $(\mathrm{Mn}, \mathrm{Zn}, \mathrm{Cu}$, and $\mathrm{Fe}$ ) that could be also the raw material for further high valued products like enzymes (Tabrika et al., 2019). There is a current trending concept known as the economic values of post-harvest agricultural materials describes as a process of 3Rs: Reduce, Recycle and Reuse to convert the agricultural waste stream into valuable biomaterials for a circular economy (Trung Hai and Anh Tuyet, 2010). This conversion process involves several steps: waste separation (sorting), processing facilities setting up, market development for value-added products, and finally the organization of all connected marketing logistics.

2.4.1 Compost

The most familiar product generated from decaying organic materials is called compost and contains essential nutrients for crop production (Van der Wurff et al., 2018). This organic product is obtained through an aerobic process whereby microorganism activities transform the organic materials into a stable and hummus-like product called Compost (Pergola et al., 2020). The proper use of compost is indispensable in agriculture because too low application leads to nutrient deficiency in the soil but again too high application causes changes in soil composition (nitrate leaching and phosphorus runoff). The processing of organic wastes into compost with the circularity approach was successfully implemented as a business model in Ghana. The collected organic wastes from markets were transported to a composting facility, and after processing activities the compost was sold to farmers by unemployed young people who welcomed that opportunity to earn a small income. This concept may be replicated across many African countries as a sustainable approach for agriculture development (Bianchi et al., 2020).

2.4.2 Animal feed

Currently, human food is mainly produced from plant and animal sources. Farm crop residues have been used for ruminant feeding as an alternative use to avoid burning or composting them. The land reserved for crop production is not expanding while the crop farm-residues are produced without additional input (land, water). This creates an opportunity for crop farm-residues nutrient to serve for animal feeding purposes (Madhu Mohini, 2015). Due to the chemical composition, crop farm-residues have to be treated before being given to animals. Several physical 
(chopping), Chemical (soaking in Alkali), biological (Karnal process) treatments have been tried by both researchers and farmers with the aim of deconstruction of lignocelluloses components to ease the digestion by animals. Nevertheless, further 'food-feed crops research' is crucial to moderate future global animal feed demand without human food scarcity (Madhu Mohini, 2015).

\subsubsection{Briquette}

The term "briquette" is derived from the French word "brique" meaning brick. It is known as a compressed block of coal dust or other combustible biomass material used as fuel and starts a fire. Agricultural wastes produce biomass briquettes. These crop-based energy generation materials are divided into two types: crop residue briquette and agro-industrial briquette. According to Kpalo et al., (2020), the crop residue briquettes are produced from any crop farm-leftovers (leaves, twigs, roots ...) while agro-industrial briquette is manufactured from processing industry waste (cassava peel, bagasse, coconut shell...). The briquettes are biomaterials utilized in rural and urban places for both domestic and industrial heating application and energy production (gasification). They are used as an affordable alternative source to replace firewood, charcoal, or other solid fuels (Kpalo et al., 2020). 2.4.4 Biochar

The crop organic material consists of three main components lignin, cellulose, and hemicellulose. At elevated temperature, those materials are broken down in simple compounds and this process is known as thermochemical depolymerization reactions. The thermochemical decomposition "pyrolysis" of biomass, generally, takes place in an oxygen-free environment within a temperature range of $300-500{ }^{\circ} \mathrm{C}$ to produce the char (Sakhiya, Anand and Kaushal, 2020). This bio decomposition process converts low-energy-density biomass into a high-density liquid product called "bio-oil", medium caloric value gas called "synthesis gas", and high-density solid product called "biochar". After its production, biochar must be activated before its application for various purposes. The activation here means a technique applied physically or chemically to biochar to improve its physical characteristics (i.e. specific surface area) and absorption capacity (Sakhiya, Anand and Kaushal, 2020). The activated biochar serves multiple purposes like soil amendment in agriculture, absorbent of contaminant and pollutant in aqueous solutions; it can be used also as catalysts of chemical reactions, fuel alternative, used as an additive, used in the construction sector.

2.4.5 Bio-Based packaging materials

Majority of packaging materials are made from plastic materials which are not biodegraded and become a source of environmental pollution. Nowadays, as the technology is advancing some alternative natural packaging material is manufactured and cellulose, a polysaccharide, is one of the most used biopolymers as raw material. Cellulose is a polymer originating from the plant material and is made of $\beta$-D-glucose subunits. Naturally, cellulose is not good raw material for packaging material due to its very low water solubility (Reichert et al., 2020). However, plasticizing, surface modification, coating, and blending are used to modify the natural condition of cellulose and become water-soluble. Thus, modified cellulose with the addition of plasticizers serves a raw material for film formation as one type of bio-based packaging material.

\subsection{Technical and Vocational Education Training in Agriculture}

Generally, the global economy generated from various domains of production involves two-thirds of the workforce (technicians, specialists) to perform technical activities. These skilled people are trained by experienced teachers and trainers from various domains of Vocational Education helpful for Human Resources Development (Grollmann \& Rauner, 2007). Considering the importance of vocational training for economic success, especially its link with the agricultural value chain, it is noticeable that in many countries, TVET education is not directly and fully involved in the agriculture development and consequently failure to achieve the professional and social collaboration between agriculture players and TVET institutions.

\subsubsection{IPRC Musanze Description}

One of the eight colleges of Rwanda Polytechnic named IPRC Musanze is located and operating in the Northern Province of Rwanda in Musanze District, Nkotsi Sector, Bikara Cell, and Barizo Village. IPRC Musanze is a public TVET higher learning institution, offering practical training, applied research, and participation in community outreach activities to contribute to the social welfare of its neighbouring community. IPRC Musanze has five teaching academic departments namely: Agriculture and Food Processing Department, Irrigation and Water Engineering Department, Hospitality Management department, Civil Engineering department, and Electrical and Electronics Engineering department. The aim of the Agriculture and Food Processing Department at IPRC Musanze is to contribute to Rwandan agriculture transformation from the subsistence to a modern and income-oriented agriculture with the overall mission of improving people's lives. This is mainly done through academic training, applied research, and community outreach initiatives (IPRC Musanze, 2020). The college offers also short courses of three months, four months, six months, or one year in the following trades: Carpentry, Culinary Arts, Electrical Domestic Installation, Food and Beverage Service, Food Processing, Front Office, Housekeeping Operations, Masonry, Plumbing and Welding. In a wide perspective, the IPRC Musanze mandate is not only training but also the involvement in community outreach services and solution-based applied research. 
Since its establishment in 2015, IPRC Musanze has various achievements by which in collaboration with local leaders, the college built a house valued to 16 million Rwandan Francs for vulnerable survivor orphans of the 1994 genocide against Tutsi. IPRC Musanze staff and students participated in many community outreaches like donating Health insurance to poor and vulnerable citizens, giving cows to families for malnutrition prevention and contributing to the social economy, providing small start-up capital for some entrepreneurs with limited capacity. IPRC Musanze has 76 academic teaching staff whereby $15 \%$ of them are females while $85 \%$ are males. Majority of academic staff are bachelor's degree holders with five years' experience which are basic requirements for teaching at IPRC College. IPRC Musanze staff benefit from existing collaboration with different partners (SEAD Project, Jinhua Polytechnic, Technoserve, APEFE) in terms of short course training as one of a staff motivational channel. Besides, the college has the staff capacity building strategy whereby two teaching staff from any department is allowed for further studies (master or $\mathrm{PhD}$ studies) related to their field of specialization.

\subsection{Farmer-Academia relationships}

In the horticulture value chain, functions are performed by blended actors with different but complementary activities. One of the keys involved actors in any value chain environment is known as chain supporters such as academic training and research institutions among others. From experience, academic training and research activities are observed as a one-way initiative designed by academicians and researchers with minimal or without input from beneficiaries, whereby even the implementation of interventions or programs are done without any strong involvement of beneficiaries (Drahota et al., 2016). This approach results in a weak collaboration between academics and community stakeholders as a source of failure to translate university-based findings into "realworld" settings.

The crucial concept of community-academic partnerships (CAPs) life is based on innovations or applied initiatives that involve all players on the ground (trainers, researchers and beneficiaries) because it is beyond an academic environment and touches the community where it should make an impact on their ways of doing. The successful partnerships between academia and community may improve communication and cooperation between both parties and result in realistic ways of working that fill the gap of translation of academic research findings into community real-life practice (Drahota et al., 2016). The overall goal of any partnership involving agricultural farmers is farming profitability improvement and one way to achieve this is to make use of the agricultural wastes as utilizable as possible because they are natural biological resources not just refused and discarded. Sabiiti (2011) suggests the setup that can tie together farmers with their potential of agricultural wastes as raw material from their farming activities and other institutions with technical capabilities (skills, knowledge, facilities) to create economic values out of the agricultural residues. This is the reason why a partnership within value chain actors is needed for better future performance for the benefit of all. Scientific knowledge that does not make the required contribution seriously hinders university-industry collaboration. If the universities are not creating knowledge and skills and disseminate it to solve industry problems, the industry will remain ignorant and reluctant to apply the new technologies discovered by the universities (Sannö et al., 2019).

\section{Research methodology}

\subsection{Research Strategy}

The study was carried out in Rwanda, Northern Province, and Musanze District in Nkotsi Sector. The quantitative and qualitative approaches were used to get data from respondents and key informants. The online semi-structured questionnaires were given to tomato farmers and IPRC Musanze TVET trainers whereas the online semi-structured interviews were also done for various key informants from public and private institutions in close connection with horticulture sector development.

\subsection{Target population}

The studied case was tomato farmers in Nkotsi Sector from Musanze District. The sample population was from this high tomato producing area, which is also the location of IPRC Musanze. The target population was 50 tomato farmers operating in five (5) cells of Nkotsi sector and the 13 IPRC Musanze TVET trainers from the Department of Agriculture and Food Processing. Twelve key informants were targeted from public and private organization closely involved in the horticulture sector development in Rwanda.

\subsection{Sample size}

Thirty-five (35) respondents were sampled from five cells of Nkotsi sector from which seven (7) tomato farmers were representative of remaining fellow farmers for each cell. A total of thirty-four (34) farmers responded to the online semi-structured questionnaire about their farming experiences. All thirteen (13) IPRC Musanze TVET trainers from the Department of Agriculture and Food Processing were purposively chosen. A total of six (6) key informants from public and private institutions were interviewed on their experience in horticulture sector development. 


\subsection{Sampling Techniques}

A total of thirty-five (35) tomato farmers were randomly sampled among the sample population while all thirteen (13) IPRC Musanze TVET trainers were purposively chosen from the Agriculture and Food Processing Department. The six (6) key informants were purposefully chosen from public and private institutions with remarkable involvement and experience in horticulture sector development.

\subsection{Data collection instruments}

The current study was carried out with the aid of two different semi-structured questionnaires to collect primary data from tomato farmers and TVET trainers. The semi-structured interviews were designed to collect data from key informants who provided additional information required for the study. The search engines were consulted for secondary data collection.

\section{Results and discussion}

The findings of this study are presented following the research objective which was to identify potential value addition activities to tomato crop farm-leftovers and investigate the current farm-leftovers uses, to suggest collaboration model between tomato farmers in Nkotsi Sector and IPRC Musanze as a channel of solutions provision on tomato farming development challenges. The researchers used different semi-structured questionnaires to get data from the concerned respondents and the semi-structured interview to get additional information from key informants. The summary of respondents' views is presented in the following paragraphs.

\subsection{Results from farmers' online Survey}

29 out of 34 farmers responded to have more than 4 years of tomato farming experience. $29 \%$ of respondents confirmed that the tomato stems are the most leftovers in their tomato farms. The $59 \%$ of respondents said that the generated tomato crop farm-leftovers are used for compost making, while only $18 \%$ of respondents said that the generated farm-leftovers remains unused at farm level, $18 \%$ respondents said that the tomato crop farm-leftovers remain unused and sometimes used as mulching, and 5\% respondents use tomato crop farm-leftovers for feeding animals and making compost and no one mentioned burning practice of farm-leftovers. $100 \%$ of respondents said that they do not gain any monetary benefit (cash) while using the tomato crop farm leftovers for different purposes. $91 \%$ of respondents are not aware of the negative impact of crop farm-leftovers on their farming practices and the environment. $100 \%$ of the respondents said that they know IPRC Musanze in different views.59\% of the respondents confirmed that they know the IPRC Musanze community outreach activities done to its surrounding communities.97\% of the respondents have no previous collaboration with IPRC Musanze $97 \%$ of the respondents are willing to have future collaboration with IPRC Musanze in different areas. Tomato farmers in Nkotsi sector suggested different areas for future collaboration with IPRC Musanze. Technical Training and Joint Business Ideas were mostly suggested by $38 \%$ of respondents. The tomato farmers who responded to the online survey suggested three main areas of improvement which are: postharvest handling, farm crop residues management and farming practices with $77 \% ; 62 \% ; 54 \%$ of respondents respectively. The harvesting techniques were least suggested by only $31 \%$ of respondents.

\subsection{Results from TVET Trainers Online Survey}

The responses from online TVET trainer survey shows that IPRC Musanze can provide support to tomato farmers in Nkotsi sector through various technical training activities such as Good Agriculture Practices, Post-harvest, Farmer Field School, Joint research and innovations, and various consultancies. 92\% of the responded trainers previously participated in different community outreach activities organized by IPRC Musanze.62\% of the respondents confirmed that there are no advanced tomatoes farming activities present in Nkotsi Sector. $92 \%$ of the respondents confirmed that crop farm-leftovers have effects on farming activities as well as the environment.69\% of respondents agreed that tomato crop farm-leftovers are mostly used for compost making while $15 \%$ disagreed.46\% of respondents agreed that tomato crop farm-leftovers are mostly used for feeding animal while $31 \%$ disagreed.46\% of respondents agreed that tomato crop farm-leftovers can be used as raw material for other products. $69 \%$ of respondents strongly disagreed that tomato crop farm-leftovers are useless while only $8 \%$ agreed.46\% of the respondents suggested that the technical training and Joint research and innovation activities are the suitable collaborations that could be established between tomato farmers in Nkotsi sector and IPRC Musanze.

\subsection{Results from in-depth online interviews}

The tomato farming in Nkotsi Sector is considered as small scale and its moderate primary production generates comparative farm-leftovers. One of the interviewees confirmed the available opportunities that can help tomato farmers in Nkotsi sector to scale up to medium farming. All key informants reported that they do not know any other products that can be manufactured from tomato crop farm-leftovers apart from compost. Even though key informants do not recognize any other product made from tomato farm-leftovers, they confirmed the importance 
of the leftovers in farming activities. $100 \%$ of the key informants were curious and suggested further studies on the manufacturing process and trials or prototypes of new products made from tomato crop farm-leftovers.

\subsection{Ways of collaboration between IPRC Musanze and Tomato farmers}

The insights from key informants on possible collaboration between tomato farmers and IPRC Musanze are clear and promising but also conditional and require steps for its implementation. Beforehand, the identification of farmers who can understand the partnership concept is one of the first steps. Farmers should be aware that the college is willing to collaborate with them and be explained the purpose, responsibilities and benefits of each party before any engagement is done. IPRC Musanze as a TVET school, they intend to strengthen cooperation in terms of training people who are willing and reside near the campus. The existing collaborations between IPRC Musanze and farmers are done through Memorandum of Understanding with big farmers or cooperatives while small farmers are just supported. The farmers can appreciate and adopt a proposal given to them depending on the level of involvement in its concept from the beginning. When farmers understand and are involved in the designing of the concepts it is even easier to mobilize and explain to them the benefits for organized farmers' groups. Therefore, through continuous stable relations and trust creation, the establishment of farmers' groups should be an easy way for better coordination, quality and quantity production, and from there the long-life joint activities for both parties are assured. Once the partnership is agreed, it should be governed by a signed agreement that describes the roles and responsibilities of parties, thus IPRC Musanze needs to be in constant communication with the farmers for smooth implementation.

The possible joint activities that could be done by IPRC Musanze and tomato farmers have been identified and hereafter described. IPRC Musanze can provide improved seeds developed from its greenhouse, give technical assistance on the field, involved in the farming system while the farmers can avail the land from which the farming activities could be performed. Through the usual collaboration with Musanze District/Nkotsi sector and RAB, IPRC Musanze via Agriculture and Food Processing Department can organize sensitization on land consolidation and training about GAPs (e.g. pest and disease control), improved compost making, postharvest handling and value addition to tomato crop. The IPRC Musanze support can be expressed in terms of training, research and innovation activities responding to local challenges and providing solutions. The emphasis should be on the crop breeding where IPRC Musanze students and academic staff can focus on crop multiplication that should be adopted by farmers following the facts from successful laboratory trials.

\subsection{Proposed collaboration model}

The information garnered from key informants and surveys' respondents show that there is no formal and structured collaboration strategy between IPRC Musanze and tomato farmers. However, some social-oriented community outreaches have been organized by the college some neighbouring citizens benefited. The respondents provided insights into the possible collaboration model based on the interests and benefits of both parties. The proposed model should begin with establishing stable relations and trust amongst involved parties. Relations can refer to linking intervention activities from both parties (community outreach, training) while trust is defined as firm beliefs and reliabilities with facts of the abilities/capabilities of each party that are in place at the beginning of any collaboration. Additionally, the interests of both parties should be well described and understood beforehand. The college interests lie in quality technical training at all levels, impactful societal contributions (research, innovation, and outreach) while farmers are interested in improved quantity and quality production, secured market and maximized incomes.

In any collaboration, parties foresee benefits brought by the collaboration outcomes. During the implementation of the proposed farmer-academia collaboration model, IPRC Musanze will benefit from improved quality of training, students' exposure to the practical field of experience, improved institutional branding and corporate image, published applied research papers while farmers will benefit from acquiring new knowledge and hands-on skills, applying modern farming techniques, and also gain from IPRC Musanze capabilities (technologies, equipment, skilled staff, consultancy). Beyond the direct collaboration of beneficiaries, the dual facet outcomes will reach to the society in general, starting to a nearby community, regional, national and international levels. Outcomes from the collaboration will provide benefits to the society through new sets of job creation, new opportunities to diversify production/activities and new opportunities to sustain the environment. Figure 1 illustrates the proposed farmer-academia collaboration model between IPRC Musanze and tomato farmers. 


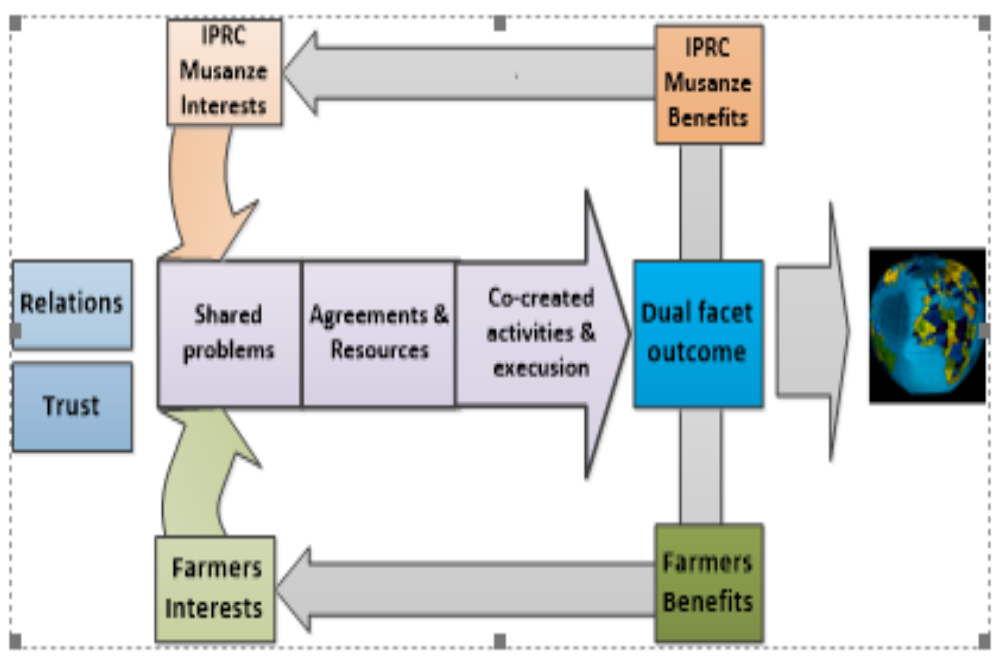

Figure 1: Model of collaboration between IPRC Musanze and tomato farmers

\subsection{Discussion of the results}

This study reveals that the major and only tomato crop farm-leftovers usage in the studied area reflects the farmers' limited knowledge in value addition techniques that can be applied to tomato crop farm-leftovers to process other valuable products. Even though the way composting is done; burying the tomato crop farm-leftovers is not professional. Feeding animals and mulching are additional uses of tomato crop farm-leftovers in the region. The tomato farmers in that region are neither aware of any negative impact of farm-leftovers on their farming activities and the environment nor the opportunity a source of monetary benefits. All responded farmers do not gain any money from tomato crop farm-leftovers generated from their farms. Consequently, there are no value addition activities done on the tomato crop farm-leftovers and even the composting activities performed are not profitably valued to generate additional income to the farming business. Therefore, tomato farmers in Nkotsi sector lack knowledge and practical skills and the areas of improvement for their farming business and the application of agricultural best practices, post-harvest handling, and farm crop residues management. The majority of TVET trainers (62\%) from IPRC Musanze in the Department of Agriculture and Food Processing confirm the absence of advanced tomatoes farming activities in the region. This situation reflects farmers' limited knowledge and skills in updated farming techniques and lack of capital investment in advanced farming infrastructures; consequently, improperly managed tomato crop farm-leftovers affect the farming activities as well as the environment. From this basis, TVET trainers confirm again the uselessness (in terms of money generation) of tomato crop farm-leftovers generated from farms. Nevertheless, they agree on the only possible technique used by farmers to add value to their crop farm-leftovers through compost making.

On the other hand, TVET trainers mention activities to be carried out to contribute to the above-mentioned existing problems. Technical agricultural training for farmers and applied research and innovation are the main activities to start with as they belong to the primary interests of TVET School. The information obtained from indepth interviews confirms that apart from compost made from tomato crop farm-leftovers there are no other known products currently made from those organic materials. With curiosity, all informants recommend further research on products that can be manufactured from tomato crop farm-leftovers to help farmers generate additional income to their tomato farming business. The use of a low, medium, and high technology resulting into the low-value products (compost, animal feed), medium value products (biochar, briquette) and high-value product products (bio-based packaging material, enzymes). The crop leftovers valorization is a process that needs resources from different players and the reason why it needs the cooperation of different stakeholders.

The big challenge may arise when the initiative is adopted without a clear plan for product manufacturing which requires enough raw material (farm-leftovers) that are obtained from primary production. Therefore, the process should be understood from the beginning to avoid miscommunication and complaints that could arise along the implementation stages. The discoveries of other products made from tomato crop farm-leftovers are possible through the partnership of willing parties. The collaboration between IPRC Musanze and tomato farmers is possible based on previous experience where the college collaborated successfully with maize farmers. Two major preliminary conditions to be in place beforehand are stable relations and trust between parties.

The long-term collaboration involving different participants is not a one day implemented intervention it requires trials to test its practicability. Therefore, a piloting phase of the collaborative model between the college and few identified tomato farmers is the starting point, then after its evaluation, the expansion to the whole Nkotsi sector may be done. For whatever cases, the collaborative activities should be governed by clear and designed agreement for the interests and benefits of both parties. Some farmer-academia collaborative activities may be the 
development and farming improved seeds, the postharvest handling activities, problem-solving applied research, and agriculture-related innovation initiatives.

\section{Conclusion and recommendation}

This paper identified the potential value addition activities to tomato crop farm-leftovers and investigated the current farm-leftovers uses, to suggest a collaboration model between tomato farmers in Nkotsi Sector and IPRC Musanze. The surveys and in-depth interview results confirm that tomato farming in Nkotsi sector is at a smallscale level, with individual farmers and moderate primary production of tomatoes, thus relatively farm-leftovers quantity is generated. The most generated farm-leftovers are stems while leaves and roots are also present in the tomato farms. All produced tomato farm-leftovers are mainly used for compost making and a limited quantity is used as animal feeds, mulch, and used as a fire source for cooking. The study results revealed that in whatever end-use of tomato crop farm-leftovers, they do not generate any additional money to the farmers. Composting is the only farm-leftovers management technique practised even though it is not professionally done. The farmers' limited knowledge and skills, absence of agricultural-related applied research and innovation, and the inexistence of farmer-academia collaboration are the main reasons why the farm-leftovers are not transformed into other different valuable crop-based products in Nkotsi Sector.

Based on its previous experience, IPRC Musanze is willing to strengthen the collaboration with farmers in line with its mandates and capacity in practical training to all levels and carrying out impactful community outreaches. There is a need of the long-term collaboration whereby several possible value addition processes can be applied to tomato crop farm-leftovers to improve the tomato farming subsector in Nkotsi Sector and simultaneously boost the quality of practical training offered by the college.

The sustainability of farmer-academia collaboration will depend on the involvement of farmers in the concept designing process and the commitment and leadership of the college. The discussion about the potential opportunities, the mutual benefits of the cooperation, and the piloting plan of activities are the key factors for the long-life of the partnership. Thus, the collaboration between tomato farmers and IPRC Musanze is possible and should be mainly based on technical training, joint problem-solving initiatives, applied research, and the provision and farming of improved seed. Therefore, the proposed farmer-academia collaboration model between tomato farmers and IPRC Musanze should be initiated by the college. The initiative should start with academic staff assigned to carry out applied research, with students' participation. Through the close involvement of a few selected neighbouring farmers representing their fellows, IPRC Musanze will play a decent contribution to the farming development and valorization of the tomato crop in Nkotsi Sector.

About the study findings, the following recommendations would improve in tomato farming. With the help of Nkotsi Sector agronomist, one willing and capable tomato farmer should be selected to represent his/her cell in the piloting process of the collaboration. Tomato farmers in Nkotsi Sector might begin notifying IPRC Musanze, as TVET School in their location, the farming challenges that need to be addressed by academic experts from the college. Tomato farmers in Nkotsi Sector might commence upgrading their small-scale farming business to medium and large-scale farming to access to several support services offered by different stakeholders. Through its specific teaching department, IPRC Musanze should organize and carry out periodically Good Agricultural Practices training to tomato farmers in Nkotsi Sector. The emphasis should be on problem-solving applied research, innovation, and dissemination of research findings to respond to existing farming challenges which will also enhance the quality of training. The farmer-academia collaboration model should be piloted on a few committed farmers as the starting point for sustainable future collaborations involving farmers' participation. The decentralized local administration, at the Sector level, should encourage and facilitate tomato farmers' group formation to facilitate access to supporting services from different stakeholders. The Nkotsi sector in collaboration with Rwanda Agriculture Board Musanze station should facilitate land consolidation in Cyizi marshland in Nkotsi Sector to ease the application of modern agriculture practices that boost tomato production. Further research should be done on the manufacturing process, trials and cost analysis for the low-value-added products, medium-valueadded products from tomato crop farm-leftovers. With the involvement of other key stakeholders, the created tomato farmers' groups should be supported as the starting point for farmers' vertical integration into the tomato value chain.

\section{References}

Ari Aprianto, D., Daryanto, A. and Sanim, B. (2016). “Analysis Value Chain of Green Productivity in Natural Rubber Cultivation Process at Kelompok Usahatani Restu2”. International Journal of Science and Research, $5(8)$.

Bianchi, F., van Beek, C., de Winter, D. and Lammers, E. (2020). Opportunities and Barriers of circular agriculture: Insights from a Synthesis Study of the Food \& Business Research Programme. [Online] NWO. Available at: https://www.nwo.nl/en/research-and-results/cases/rethinking-agricultural-foodproduction.html [Accessed 10 May 2020]. 
CBI (2015). Value Chain Analysis Report. Kyiv: Ministry of Foreign Affairs.

Crump, A. (2016). Horticulture CRSP Annual Report 2012. [Online] USA: Horticulture Innovation Lab. Available at: https://horticulture.ucdavis.edu/sites/g/files/dgvnsk1816/files/extension_material_files/2012-annualreport.pdf [Accessed 10 May 2020].

Donovan, J., Franzel, S., Cunha, M., Gyau, A. and Mithöfer, D. (2015). Guides for value chain development: a comparative review. Journal of Agribusiness in Developing and Emerging Economies, 5(1), pp.2-23

Drahota, A., Meza, R.D., Brikho, B., Naaf, M., Estabillo, J.A., Gomez, E.D., Vejnoska, S.F., Dufek, S., Stahmer, A.C. and Aarons, G.A. (2016). Community-Academic Partnerships: A Systematic Review of the State of the Literature and Recommendations for Future Research. The Milbank Quarterly, 94(1), pp.163-214.

FAO (2019). FAOSTAT. [Online] Fao.org. Available at: http://www.fao.org/faostat/en/\#data/QC/visualize [Accessed 14 May 2020].

Fortune of Africa (2013). Tomato. [Online] Fortune of Africa Rwanda. Available at: https://fortuneofafrica.com/rwanda/tomato/ [Accessed 13 May 2020].

Fritsch, C., Staebler, A., Happel, A., Cubero Márquez, M., Aguiló-Aguayo, I., Abadias, M., Gallur, M., Cigognini, I., Montanari, A., López, M., Suárez-Estrella, F., Brunton, N., Luengo, E., Sisti, L., Ferri, M. and Belotti, G. (2017). Processing, Valorization and Application of Bio-Waste Derived Compounds from Potato, Tomato, Olive and Cereals: A Review. Sustainability, 9(8), p.1492.

Grollmann, F. and Rauner, F. (2007). International Perspectives on Teachers and Lecturers in Technical and Vocational Education. Netherlands: Springer.

Handayati, Y., Simatupang, T.M. and Perdana, T. (2015). Agri-food supply chain coordination: state-of-the-art and recent developments. Logistics Research, [Online] 8(1). Available at: Https://link.springer.com/article/10.1007\%2Fs12159-015-0125-4 [Accessed 10 May 2020].

IPRC Musanze (2020). Home. [Online] www.iprcmusanze.rp.ac.rw. Available at: http://www.iprcmusanze.rp.ac.rw/index.php?id=2 [Accessed 15 Jun. 2020].

Junker-Frohn, L.V., Lück, M., Schmittgen, S., Wensing, J., Carraresi, L., Thiele, B., Groher, T., Reimer, J.J., Bröring, S., Noga, G., Jupke, A., Schurr, U., Usadel, B., Wiese-Klinkenberg, A. and Wormit, A. (2019).

Tomato's Green Gold: Bioeconomy Potential of Residual Tomato Leaf Biomass as a Novel Source for the Secondary Metabolite Rutin. ACS Omega, 4(21), pp.19071-19080.

Karim, R. and Biswas, J. (2016). Value Stream Analysis of Vegetable Supply Chain in Bangladesh: A Case Study. International Journal of Managing Value and Supply Chains, 7(2), pp.41-60.

KIT, Mali, F. and IIRR (2010). Chain Empowerment: Supporting African farmers to develop markets. Netherlands: Kit.nl.

Kitinoja, L., Motunrayo Odeyemi, O., Dubey, N., Musanase, S. and Singh Gill, G. (2019). Commodity system assessment studies on the postharvest handling and marketing of tomatoes in Nigeria, Rwanda and Maharashtra, India. Journal of Horticulture and Postharvest Research, 2(Postharvest Losses of Horticulture Crops), pp.1-4.

Kpalo, S.Y., Zainuddin, M.F., Manaf, L.A. and Roslan, A.M. (2020). A Review of Technical and Economic Aspects of Biomass Briquetting. Sustainability, 12(11), p.4609.

Kumar Sarma, P. (2018). Postharvest Losses of Tomato: A Value Chain Context of Bangladesh. [Online] International Journal of Agricultural Education and Extension. Available at: https://premierpublishers.org/ijaee/301220172862 [Accessed 11 May 2020].

LSU AgCenter (2018). Horticulture. [Online] LSU AgCenter. Available at: https://www.lsuagcenter.com/portals/our_offices/departments/spess/horticulture [Accessed 10 May 2020]

Madhovi, T. (2020). Tomato Value Chain and Local Economic Development in Domboshava Area in Goromonzi Rural District Council, Zimbabwe. International Journal of Science and Research, 9(4).

Madhu Mohini, M.M. (2015). Crop Residues for Sustainable Livestock production. Advances in Dairy Research, $02(02)$.

MIFOTRA (2017). Law $N^{\circ}$ 22/2017 of 30/05/2017 Establishing Rwanda Polytechnic Higher Learning Institution and determining its mission, powers, organisation and functioning. [Online] Rwanda: MIFOTRA. Available at: https://www.rp.ac.rw/fileadmin/user_upload/Law_establishing_RP.pdf [Accessed 10 May 2020].

Mukantwali, C., Kabayiza, E., Chahine-Tsouvalakis, H., Vasanthakaalam, H., Kilinoja, L., Wheeler, L., Singh Gill, G., Christie, S. and Sky Daystar, J. (2018). Postharvest Loss Assessment of Tomatoes in Rwanda. Rwanda: Horticulture Innovation Lab’s Reducing Postharvest Losses in Rwanda project, p.91.

Mwongera, C., Mutua, J., Koech, N., Osiemo, J., Kinyua, I. and Nguru, W. (2019). Climate risk assessment for selected value chain commodities in Rwanda. [Online] cgspace.cgiar.org. Available at: https://hdl.handle.net/10568/101430.

Pergola, M., Persiani, A., Pastore, V., Palese, A.M., D’Adamo, C., De Falco, E. and Celano, G. (2020). Sustainability Assessment of the Green Compost Production Chain from Agricultural Waste: A Case Study in Southern Italy. Agronomy, 10(2), p.230. 
RDB (2020). Horticulture sector | Official Rwanda Export Website. [Online] https://rdb.rw/. Available at: https://rdb.rw/export/export/products-directory/horticulture-sector [Accessed 10 May 2020].

Reichert, C.L., Bugnicourt, E., Coltelli, M.-B., Cinelli, P., Lazzeri, A., Canesi, I., Braca, F., Martínez, B.M., Alonso, R., Agostinis, L., Verstichel, S., Six, L., Mets, S.D., Gómez, E.C., Ißbrücker, C., Geerinck, R., Nettleton, D.F., Campos, I., Sauter, E., Pieczyk, P. and Schmid, M. (2020). Bio-Based Packaging: Materials, Modifications, Industrial Applications and Sustainability. Polymers, 12(7), p.1558.

Sabiiti, E. (2011). Utilizing Agricultural Waste to Enhance Food Security and Conserve the Environment. African Journal of Food, Agriculture, Nutrition and Development, [Online] 11(6). Available at: http://www.bioline.org.br/pdf?nd11069.

Sakhiya, A.K., Anand, A. and Kaushal, P. (2020). Production, activation, and applications of biochar in recent times. Biochar.

Sannö, A., Öberg, A.E., Flores-Garcia, E. and Jackson, M. (2019). Increasing the Impact of Industry-Academia Collaboration through Co-Production. Technology Innovation Management Review, 9(4), pp.37-47.

Singh, K., Kumar, T., Prince, Kumar, V., Sharma, S. and Rani, J. (2019). A review of the conversion of food wastes and by-products into value-added products. International Journal of Chemical Studies, 7(2) (IJCS 2019; 7(2): 2068-2073), pp.2068-2073.

Tabrika, I., Azim, K., Mayad, E.H. and Zaafrani, M. (2019). Composting of tomato plant residues: improvement of the composting process and compost quality by the integration of sheep manure. Organic Agriculture, (https://doi.org/10.1007/s13165-019-00268-0).

Trung Hai, H. and Anh Tuyet, N. (2010). Benefits of the 3R approach for agricultural waste management (AWM) in Vietnam: Under the framework of the joint project on Asia Resource Circulation Research. Hayama, Japan: Institute for Global Environmental Strategies.

UN (2016). United Nations Statistics Division - Environment Statistics. [Online] unstats.un.org. Available at: https://unstats.un.org/unsd/environmentgl/gesform.asp?getitem=1178 [Accessed 10 May 2020].

van der Wurff, A.W.G., Fuchs, J.G., Raviv, M. and Termorshuizen, A. (2016). Handbook for Composting and compost use in organic horticulture. BioGreenhouse, [Online] Handbook for Composting and Compost Use in Organic Horticulture (978-94-6257-749-7). Available at: http://dx.doi.org/10.18174/375218 [Accessed 10 May 2020]. 